\title{
THE POWER OF PARALLEL THINKING
}

\author{
Michael D. COHEN \\ Univensity of Michlgan, Ann Arbor, MI 48709, USA
}

Received Auga ist 1981, final ve rsion received March 1982

\begin{abstract}
A small computer rodel demonxl rates that an appropriate orgasization of houndedly rational individuals can find optimal polizes in an environment that is overwhelrningly complex for unorganized decision makers. The model is also used to iclentify conditions u vder which optimal - or even good - policies are not found. The denonstrated adaptive power of the model is interpreted in light of roxent dureliopments in the therry of computational con iplexity that placr nev stress on powetful methods if search, atd of $\mathrm{usw}$ models from cornputer science which markedly advance search effext veness by harnessing parallel struciures of information processing.
\end{abstract}

\section{Introduction}

The ability of organizations to adapt to the demands of their environments is an issue of major significtunce for the social sciences. As Simon (1969) has pointed out, the limits of that ability will be closely related to the approximation adequacy of rationai models of organizational action. Given its insporiance, and the extersive attention that has been directed to organization-environment r llatious [Starbuck (1976), Pfeffer and Salancik (1978), Aldrich (1979)], it is surprising that wo do not have a satisfactory account of how in organization could adapt successfully to s.n snvironmeit of any complexity.

One can, of course, simply posit that adaptation never occuri or is always perfect, but neitler of the implausible courses seems promisirg if the limits of organizational adaptation are to be studied rather than settled by assumption. To explore the niddle ground we need a thec retical account of adaptive onganizational dscis ion making that is both flausible in the face of what we know about organizations ard their component actors. and demonstrably capable of ac apting to a complex environment. It cannot viclate the former condition by ent.swing the organization or its memt rs with unrealistic volumes of information or powers of inference, tor that would cast doubt on its fidelity to cur hard-won existing knowledge of reis urganizations. It must meet ibe second condition or there is little reason to credit is patterns of limitaticn or pathology. If organizations do somstines 
adapt to compliax environments, why betisve results from a model that never

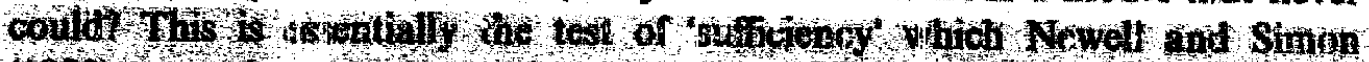

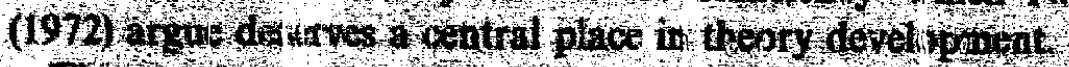

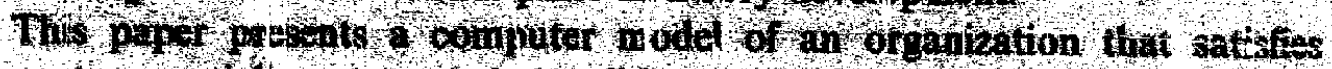
these twe patially - thepogitic conditions, ff inco porates the majer features

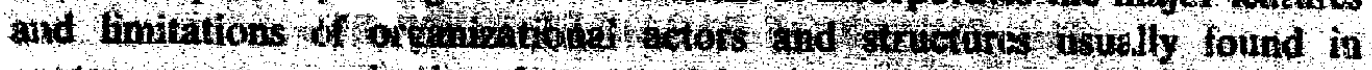
chatemporary organitation theory, and it idapt with ruming be success to

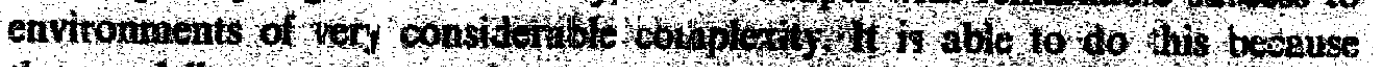

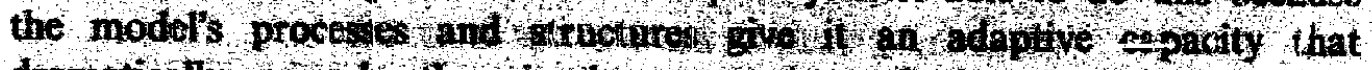
Aranatically exated the siniple summation of the espobilities of its

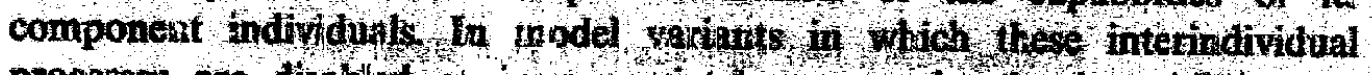
processes are dtsablat o: I Mppropinitely arrangt, adaptive abilities are orders of magnitowi weaker.

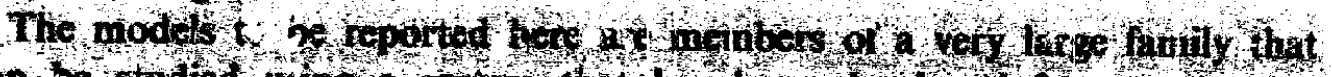
can be studied wing a spum that has toen doxolope for contrueting

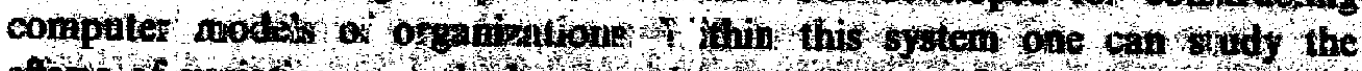

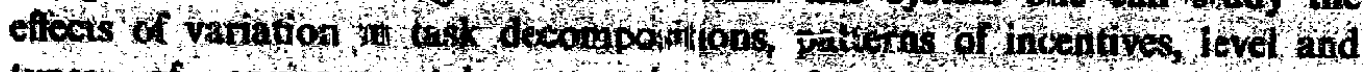

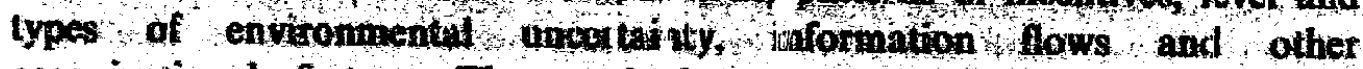
organizational fators. This method captures much of the nigor of mathematical theory and much of the richmess of verbal theory. These gains are purchased at the price of increased difficutty in the interpresation of results the in glcuter model complexity. For many purposes, however, the trade appears to $b$ s an altractive one

The modelling syogen provides modular individuars with sharply bounded information trovessing capabilities. Thus it built apon the imdamental revelations of enapirical studies of decision making [astes (1978), Anderson $(1080) 3$, hine anodel indivilusis av be assembled into virtually any otgeniatianal striture that one wants to examine and provitod with virtually any patselen of incewtives and tewards for thet towisions in effect. such a specification of rewards flowing from alternetive choices creates an environment to which the organization will adapt or, we might say a set of interretuted problens for which the mganization will search for solutions. Other factors can also be set as an investigator's interests dictate. These inciude: frim ship : 2 works, agenda for meetings, rules for making collective decigions, noise, lsis, or other environmental uncertainties, and organizatiunat precedents. Only a very few of these capabilities are exercised in the work reportid here, iowever.

Once the model is started it takes only a few seconds of computar tine for a compleie case history of onganizational decision making to unfold. Model neetings are hedd I lecisions are made Resulls of new decisions are ev luated 35 mocil individus is whose satisfaction state may charige as a result of chariges in current folicy. The mode producis interactions andung colleagues calted 'talk' proves as and thesie may lead to the proposil w' further policy 
changes. Incentives of mc. 31 tors may change. New meêings are held, and fiturycley is repeated for a fow dozen periods. The case can be recreated nandy by remoniag the not el with the same randon number seed The sensitivity of rosult can be investigated by intervening in mid-run to change particular events or by making: multiple runs with diferent random aumber seeds. Theoretically interesting pattirns can $t:$ siniacied from datia $c a$ sets of rases generated by systematicaly varying o ganizational parameters.

This vet quak aktch requines elaboration. The next section gives a fuller account of the system developed for modelling arganizational processes. the r th eomes a discission of the nature of environmental complisxity and a desctiption of the modal environment strdied here, a transportation problem orignilly posed by rantzig. This is followed by an account of the parameter settiags that were used to creat: three specific org nizational models, a basic model and two variaris. As ach of the models tries to cope with ten varitions on the model environment, they generate thirty case histories of organizational de ision making. The susceding section reports the cases and the patterns they present of stecess and failure in finding optimal organizational policiss. The fon interpretive section connects the resu'is " recently developing literatures on heuristic ipproaches to computationa" complexity and on the behavior of kystems of parellel processes.

\section{Major elements of the modelling systcm}

The models employed below : $:$ re, as noted, elements of a very large set tha can be generated by varying elenents of the org anizational modelling system. The general system is a computer program and subroutines that encod: organizational structures and p ocesses. By altering data that initializes the prograst or by small changes in the subroutines, wide variations can be indiced in organizational struclures anc processes. ${ }^{3}$ The major elements of the sysitem fall into fou: clusters.

\subsection{The policy string}

At any moment 'ne policies in effect in a model organization are represented by the state of a sixly-four bit string. The most natual interpretation is that each bit display's whether (on) or not (off) a panicular standard rperating procedurs of the organization is currently in force. For some applications very different nterpretations may be zonvenient. However. the favorer. intarpretation meshes comfortally with an evclutionary view of

\footnotetext{
'The system is in FORTRAN, and 8 transforable to most computer installatwors wizh

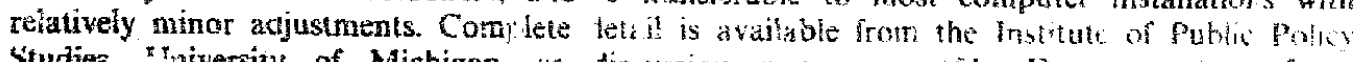

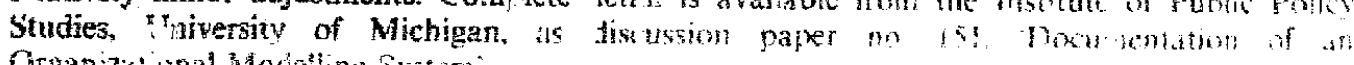

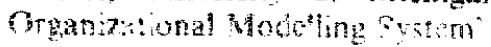


organtotic an poicy in whiclis folkowing Winter (1975), routines of the ctger " ation an trested as andogous to biological genes An individual bit

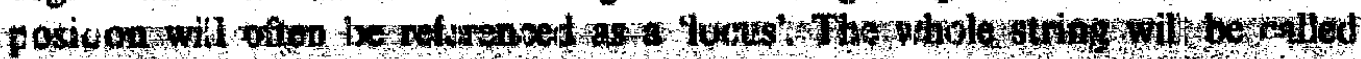

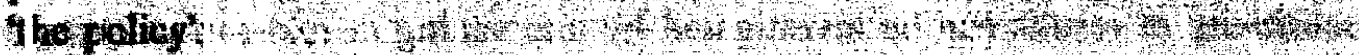

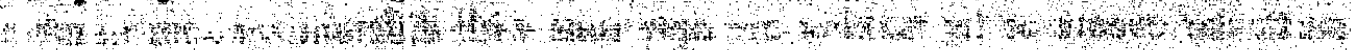

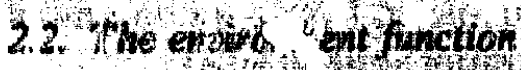

The meaning for any moviduth th the onguab ation of a particular overal

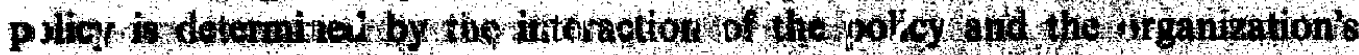

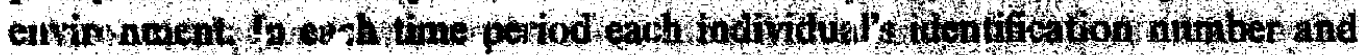

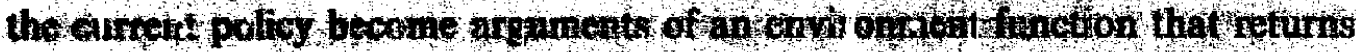

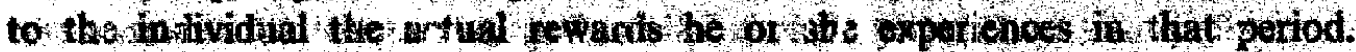
This is called operating a red hode The entwonment of the otganiration? may be sonething dfonent for erury individat and in every lime periol. The anly theoretical thrit is set by what cea b witles as a mathamatical

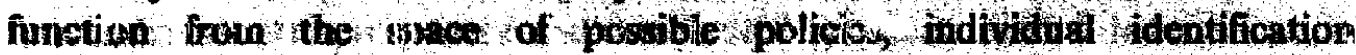
nu utrers, and timo reticets, into the rational numbers In the case resembliry the simplast firm riodols tradi oibally used in economies, al! individuals tedy have the same eavirenment function, fypically one returning the utility asscciated with o profit stream produesd by the potcy. However, the y/stem permits the study of mote complex cases in which utility functions differ among individuals, and/or change over time, and in which environmental responses to organirational policies depend of past policies.

The envirow ment iunction ma $\mathrm{y}$ also be called by an indivilual in an estimating moder a typical mod constructed in the system there will be mary suxio calls por time period Ia this mode the function returas to the individual an estimate of the rewards that would fow from some altered version of cument policy In the limiting oa which individuals osn perfecily foretell the ronifequences of alternatives, the eshimatiog mode may be identical to the real mode. The more interesting cases however will be those in which the estimates of rewards are fistorted or exroneous assessments of the actival consequexces $n^{\tau}$ a potential policy.

\subsection{Attributes of $m$ Jde! indinialuals}

An individual in anccels built with th system is represented by a. snar : set of ideas for policy inaprovements, an as, iration level, a savisfaction stato, s 20 a just-noticeable-difierence (JND). In effect, ideas are represented as sirucour bit strings from the alphabet $\{0,1,4\}$, whtre $\neq$ means 'don't cure'. an idea thus specifics a subspace of the spa ef possille policies. A typical idea for an individual will be bluk (z) on most bu not necessarily all, loci outside his or ber donain of formal resonsibility. This is due to the very fimited attention range an sharply bounded cognitive power implemented 
in the model individuals. Dperating in isolation individuals are capabie of systematic exploration of alternativ s only in their domains of formal responsibility and only of those domai as are relatively small - no more than about half addwent toel foleas about his outside the comain of responsibility mostly cone to an individual fron 1 others via or ganizational processes described in the rext section.

When at individual considers an idea, cither one self-generated or one suggested by someune else, it is evaluated by substituting current policy for all the don't care $(\#)$ loct and ther calling the elivironment function in estimating mode. This amounts to evaluating the icea by reference to the element in the idea subspace nearest to the location of current policy. In the process of retaining or discarding new ideas only orinal use is made of the resulting estimate. If the new idea has a better estim te than the worsi idea in an individual's retained set of 'good' ideas, the new idea replaces the worst member of the set. Otherwise the new idea is forgotien. The retained set of good ideas is quite small, ordinarily at out five.

Each individual also remembers an idea that incorporates the best setting so far encountered of the loci for which the individual is responsible, assuming current policy to prevail on (1ther loci. The process of considering a possible new idea is illustrated in fig. 1 .

The IND is the difference between the evaluation of the best and worst members of the set of good ideas, divided by the number of good ideas less one. The aspiration level is a weighted average of recent period rewards. The satisfaction state rises when rewards i xceed aspirations by at least a JND and falls when the opposite event oc:urs. Both high and low extrenes of satisfaction dampen somewhat indiv dual exploration of alternatives to current policy to capture the effects of ;atiation and discouragement.

\subsection{Attributes of model organizations}

The organizational structire of any model developed using this system is determined by five major components: the pattern of individual formal responsibilities: the regular meetings huld in the organizatio together with their agenda; the metho of calling irt agular or special meetings ard seting their agenda; the pr.ycesses of give and take over ideas that occur is individuals interar: an mecings; and the procedures in the organization for making authoritat ${ }^{2} \mathrm{e}$ choices of polic: The first and last of these can be altered by vaying the initializing data set. Meetings and agenda sctling wan be changed by alteing subroutines. Ic exi exchanges in meetings. which will be called 'talk' processes, are relatively nvariant piog am features.

The responsibilities of cach individ al are the lcci to which he or she predominantly attends. Ti is number $i$ limited -.. sually it is about four. Within that small domain individuals e amine deviatons from curent onlicy 


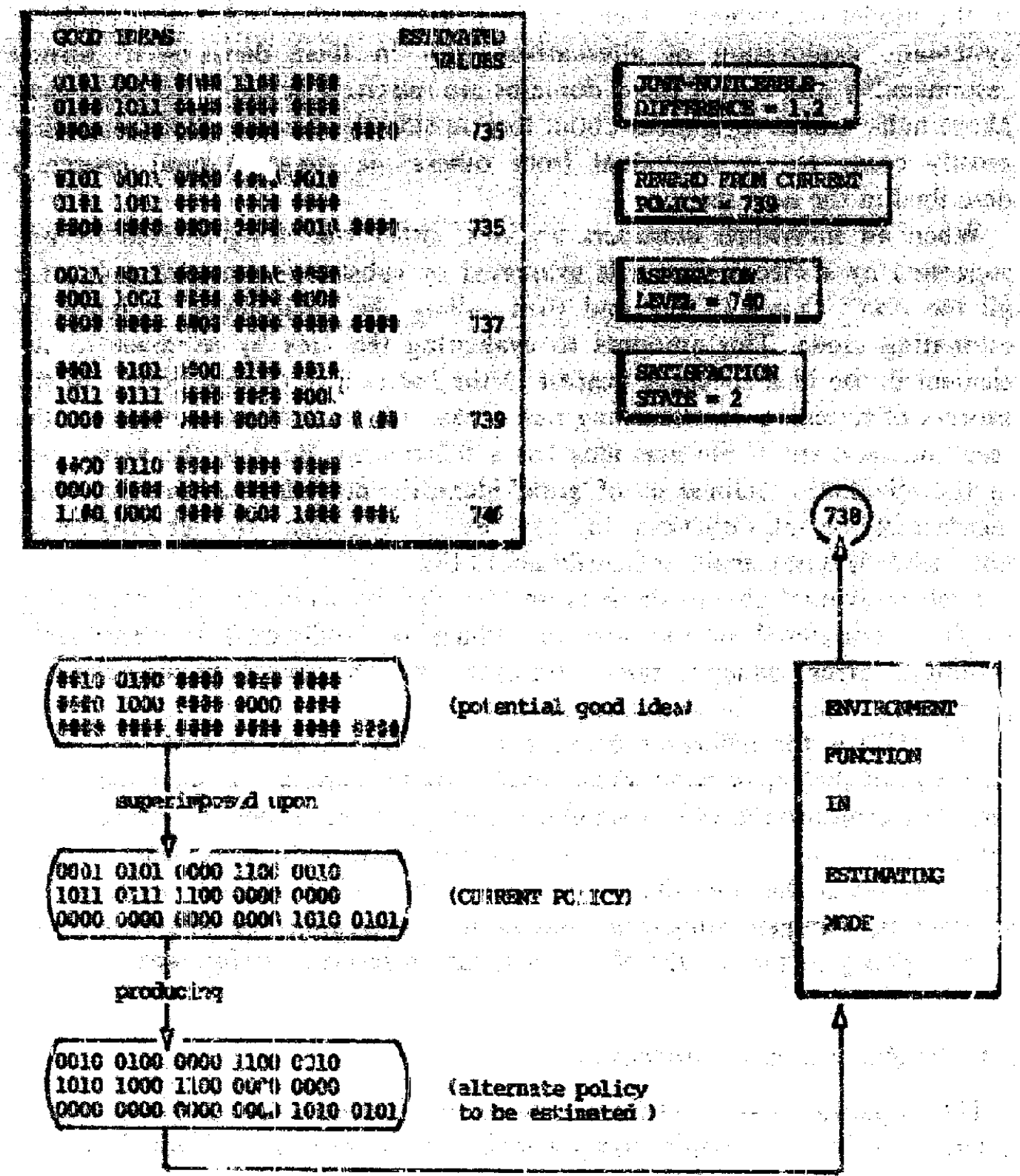

Fig. 1. Basic elements that corstitule a jypical model individua' In the situation stown a

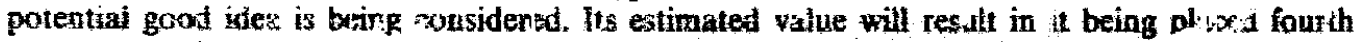
in the list of good ideas. The current fith place entry xill be droppere?

rather intensively. They do so both in iswiatiour and when sivy explore how they would respond to poliwy changes suguested by others in mretirgs. Responsibilities may also rater into the choice procedares described below. A giva a locus may have one. Theny, or no restronsible individuals.

The regalas preetings of the organization occli in overy tine period and bring logether fred sets of partipants ner open agenda. A typical axample 
of a. regular meting process assemblss meetings of individuals whose responsibilities are strongly interdepeadent. Each individual in sich a meeting proposes a change in policy drawn from his or bur list of good ideas. After the talk interaction process, as explained beiow, the organization's choive procedures are invoked and produce a change in policy or a continuation of the status quo. Then tive next meeting scheduled for the perin takes place. This example is consistent with the models reported here. For a different $y$ pe of investigation, quite clifferent regular meeting processes can be readily $d$ thed by altering the regulat m eting subroutine.

The special meeting subroutine provides a device for holding meetings over a tablext proposal that responds to parivinar problense or non-rucurring conclitions the organization may confront. An example might be a meeting called to bring together individuais for a liscussion of a policy alternative with effects that cut across the boundaries iraplied by the regular meeting stivcture.

The talk interaction processes of a model consist of two phases. The first is the simple transmission of ideas to others. $T$ he second is determining and reporting what responses an indivilual nould make in his or her own comain to idets presente: by others. Tha later is analogous to answerir 2 the question "If that idea verc in become ?xlic.", what changes would I want to make in the loci for wich I am respontible? Since the result is also in idea, there can be responses to responses to suggested ideas. ano so on. A limit of about four iterations is usually maintained. The organizaion may be provided with a cheory of txic relations bxtween loci. The theory may be vague, or erroneous, or accurate. It is used by individuals in seaiching for response to suggestions by thers since the y need to make some judgment of what implications a suggestion has for their domain of responsibility.

The choice procedures of andel specily for ectin locus the decision rule that must be used to make clianges at that locus, a precederice strusture that resolves conflicts over derision rules in multi-locus decisions, and a set of individuals who must be pres ont for choices that affect a given locus. A typical model might have majorit! rule decisinas for all loci, with responsible individuals required to be $\mathrm{pr}$ sent. An alten ne tive might give veto power over changes at some loci to particular individuals, or some loci might be subject to unilatera! changes rade by indiriduais responsible fon them. harous combinaiors of unilateral majority a id veto choice proudures cin be made by changing initial data fos a mosel run. More complax ch.nges can bo made by aitering the choice ubre atine.

To gain a sense of how r sicy, envurnument, indivinis structur, and organizational stricture a.: $=$ shined in a typical mocel it may ho to consider the cycle of events experienced by $1 \mathrm{individual}$ a one time reriod. as depicied en table 1. In an orjinary sinfe cyclo of mulei pperation an

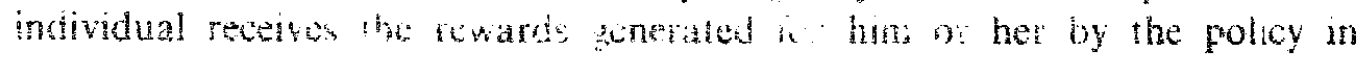




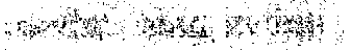

Wiblat

Tupalunetolicide

Th

4 mogers.

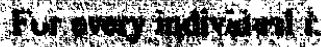

nowdros

intwoto

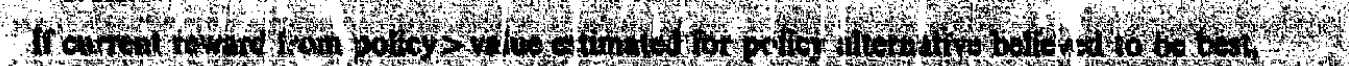

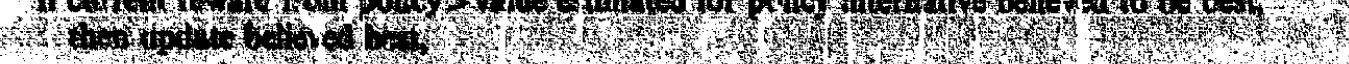

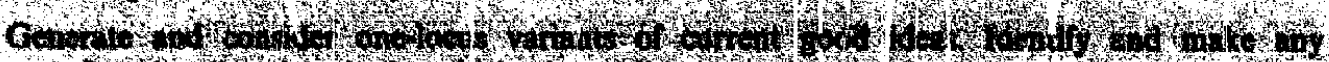

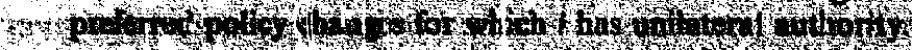

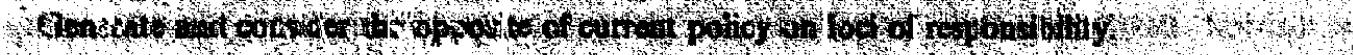

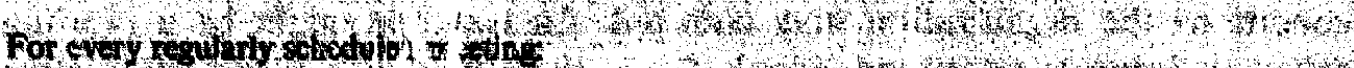

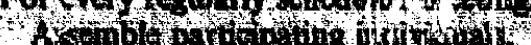

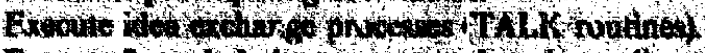

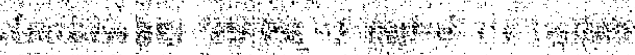

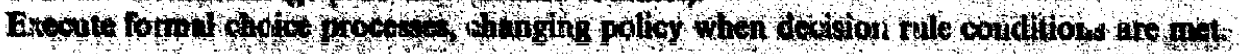

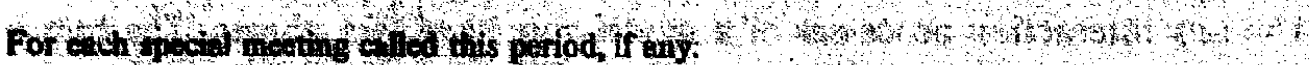

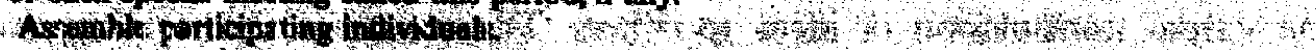

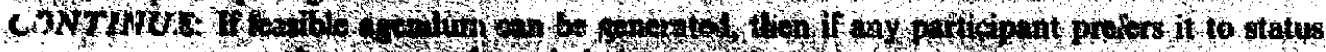

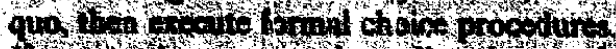

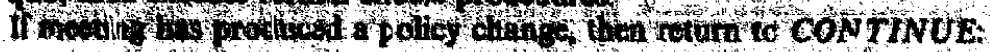

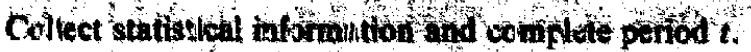

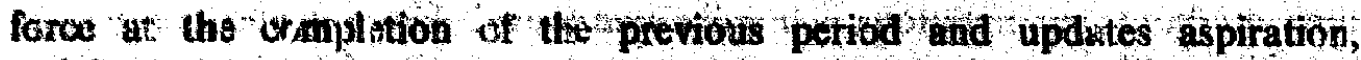

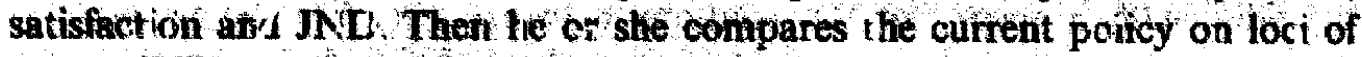
responsibiticy to the current idea of best policy on those loci. If the current policy is better, then the jdea is adjusted. The individint est nates in

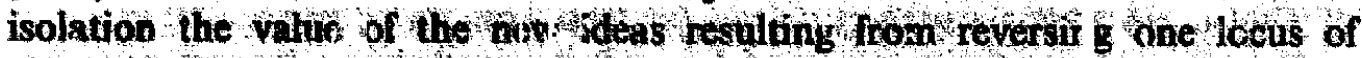
responsilitity at a time in curreht good ideas of this generates an

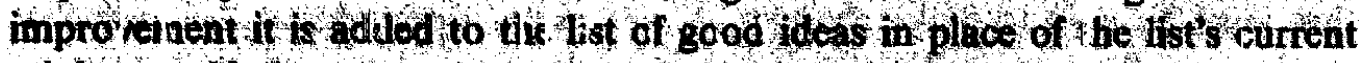
ninimum If there are any chroges that the todividual thinks would be inprowisents on loci of csponsibility and which the thavidul has authongy to wake wilaterally, they are mads. The thaividual then attends thuse meetings that are on his of her regular schedule and spoctal metings to which he or she is invited if any. On completion of whatever policy changes the metings may elgeader, reports are generated and the period comes to a close.

\section{The transport prollem envir wnment}

In using the modeling syste co ote speciffes not only a model organization, but also a model envirorment to whil it adapts. The range of possible environmant functions is la"ge, but much of the possible variation can be generted by manipulation of ons sr noie of thre fundamental factors: the 
Pittera of interactions afrong the sixty-four policy loci, the nature of temporal variation in an in dividual's real or extimated rewards from a given polfey, and the nature of interindividual differences in real or estimated revards from a given policy. For exanple; the simplest possibli snonment Wotid ro pond to each policy element equally and anunditionally, would bive ofoh individual accurate and temporally invariant estimates of the aeturas to be expopted with any purticular policy, and would give every Individual in the organization the sane 1.4 i vilue for a particular policy. In this simplestlinear case each policy locus lras a setting that is preferoble for all organizational members, and that setting is the same no matter what the setting of other loci, This envioninent prese its a perfect y deconposable probtem [Simon (1962)] to the nrodel organization and cal be solved by a moderate number of individuals in a single peri.)d. ${ }^{2}$

The linear environment without n jise, chang:, or internal conflict is: a case with winimal intrinsic aterest. Model orga izations have been un in numerous more interesting environments corre:ponding to highly non-linear integer programming problems and a progrs $\eta$ of ex ensive samping of possibie environments is now beginning. For tha present piper, however, one particular type of environment has been studiec in more detail. It is a classic family of transportation problems in 15 variables subject $t u 8$ equality constraints. Table 2 shows the most distinguished menuber of the ramily, the

Table 2

Dant $\mathrm{g}$ s original transport $\because$ ample.

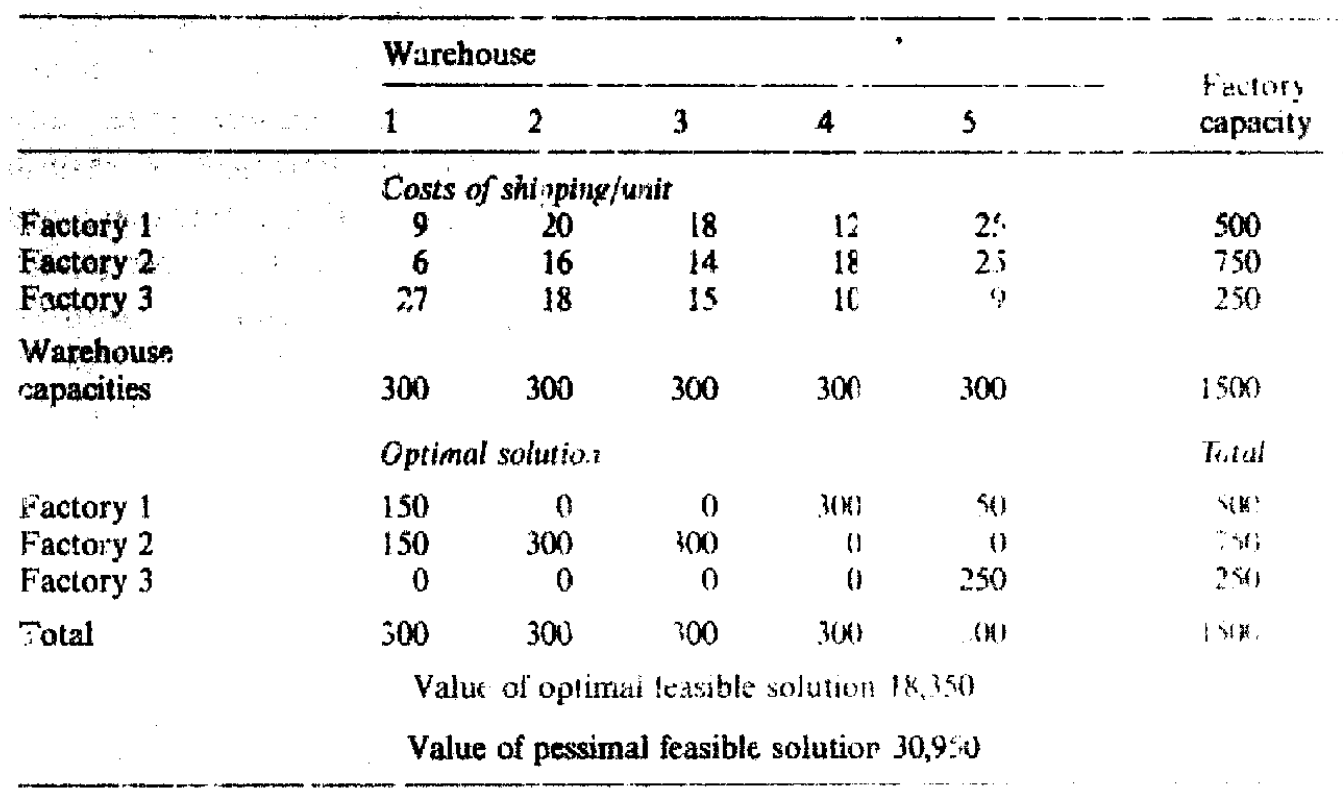

\footnotetext{
${ }^{2} A$ very small organization takes a little bonger sn 1:mited attention of the indiciduals
} 
opening exa mple of Dautaig's Inear Programming and Estensions. Dintugis upecification has ben ugmented by restrieting the veriables to integer

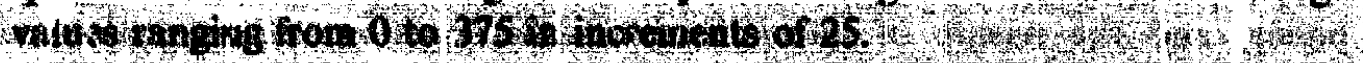

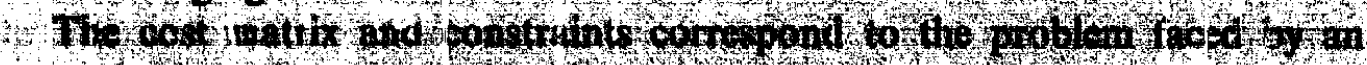

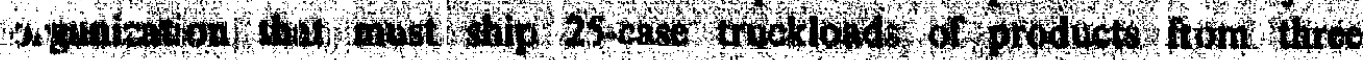

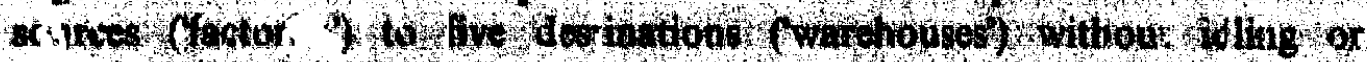

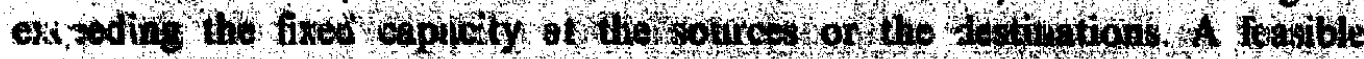

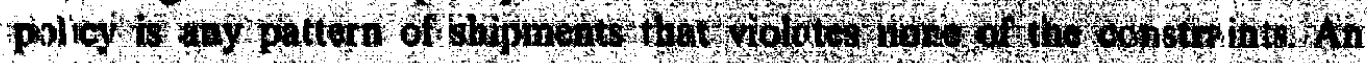

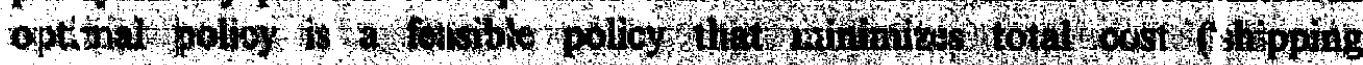

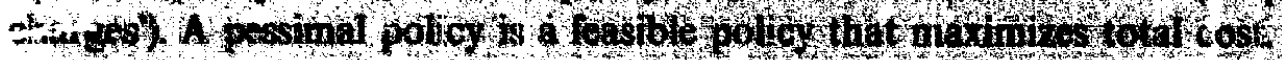

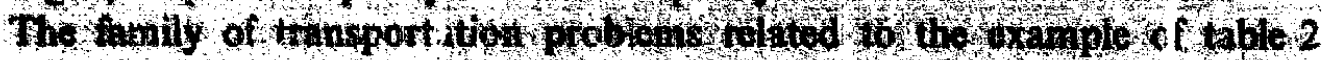

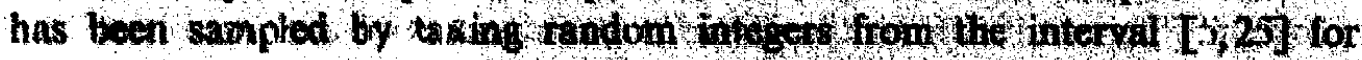
cost matrix entries. Ten I w problems were constructed in this far wion and

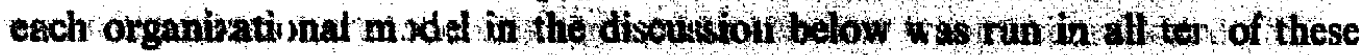

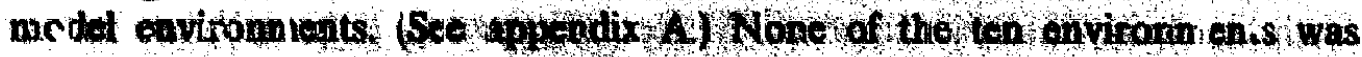
used for testing duriger noded dovelopuont

The integerizid transport problem fatnily makes a very challenging test for an organizational model. Feasible bolutions are an extremely suar e subset of all policies 3 . Folicies generated merely by chanse aro therefore neinly certain

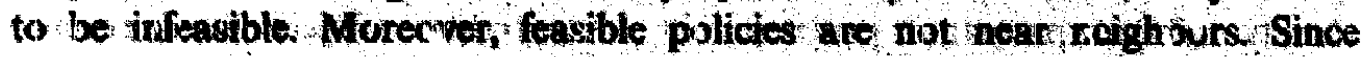
each of efteon individusils in the model is responsible for one va iable (four loci that are a binary coude for the integers 0 to 15 ), any variation of a single element of a irasible policy products an infeasible one for the models reported here. At lease fo ur loci that are responsibilities of four different individuals rast be shanged to transform one feasibe policy ir to another. As many as te losi mighi have to be reversed sirnultaneously. This means that discovering and implemunting policy changes once a feasible policy has been found is cognitively difficilt and requires the cooperation of several orgarizational mombers. When the interests of individual nembers are not identical the stage is set for what anounts to political' conflict over policy options. In essence, the integerized transport probliens present a conplex patter? that is not perfectly decomposable. They therefore provide a fundamental chalenge o the organization of a set of boundedly rafional individuals.

\section{The basic organizational model}

All the models run on these transport problems have most of their features

\footnotetext{
${ }^{3} A$ weal typer bound on the number of fasible policies can be derived by observing that there are only 91 ways a given watohouse co order 12 truckloads from three suppliers. If we ignore the fautory capacity ponstraints then have a rumber of fecsible policies $\leqq 91^{3} \leqq 6 \times 10^{\circ}$. The fiften atiatles will use no policy elements, giving $2^{60}>10^{15}$ t tal possible policies. Thenefore the densi $y$ of fe sible mil iay is less - very sunstantially less, sine have tgmored factory constraints - than on: for bu wred millson.
} 
in common. They are a selection o particular organizations from among the multitude that can be constructec with the modelling system described above $A$ number of features of the modelling system that might have introduced firther reallistic complexities were not used in these models, so as to simplity presentation and interprsation. The major features of the basic organizational model to be studied here may be grouped for description into six categories, in addition, we will examine the performance of two model variants, each of which is created by perturbing on: key feature of the basic model.

\subsection{Participants and their roles}

All three models to be considered have sixteen nembers. Each member is responsible for four policy elements, which means that the portion of overall policy with which a particular member is most coilierned can be in sixteen distinet states. Fifteen of the members have what might be called direct policy responsibilities Eaca of them must conside* what is the best level of ordering for a particular sink ('wcrehouse) srom a particular source ('factory'). The combination of three ources and lve sinks gives ifteen of these jobs. All of these fifteen individu'ls pursue the iuentical objeciive in the present nodel; for an alternative, $s w$, Cohen (198.). Possible order levels range from zero to fifteen units, whene each unit corresponds to 25 'cases' in the original Dantzig sprcification. The sixteenth mumber has a managerial role. The state of the final four poiic! elements is used by the manager to control the incentive structure under which the other fifteen members operate. Each time policy stabilizes for mole than a period with some factory constraints being violated, the manager can increase the linear) pena!ty for surh violations. Thus the manager responds simply to an observabie condition: are the factory constraints satisfied? A piecise definition of the environment faced by each individual is given in appendix B.

\subsection{Routine meetings}

The organizations all have a rou ine meeting scheduie. In ever lim: period. in every warehouse, th: three individuals who place o ders ar that warek ouse have a meeting in which wach indivituai inentions the oflernge policies currently held to be most attraitive. The thre: conside: ach wher ide:is and try to determine the inplications of the inplied chanews in whe They generate new ideas that fur $r$ ideas mentioned by others and the?" asn preferred responses to those icless. At the conciusion of a meeting 1 rmm choine procedures may lead to changes in existing policy for thei warch is that have the support of at least two of the three members. In one in the model variants these three individuals mat rot ant is from ine win. warehouse. 


\section{Sicitaluetings}

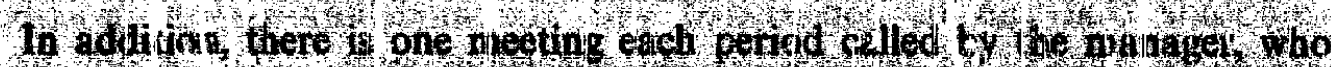
selects torn etch of 160 rafidomy chosen wiretouses two holviduals who may be nterer a 10 discuss pessible ordering pattenis a ferting both

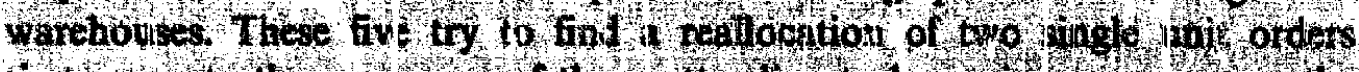

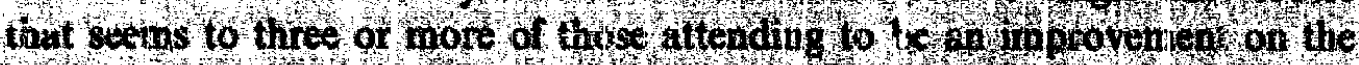

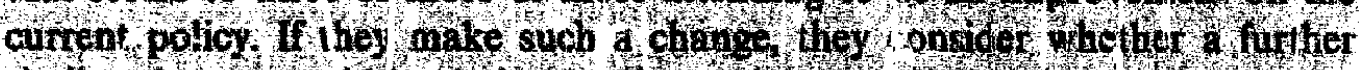
similar change would be desirable. If so, it is thade t not, the nieging ends.

\subsection{Method of chonging wathises}

In the reported un, megotity rule roting was used in meetings to deterwine whether clanges would be mide Individuals respe osille for lori under discussion wers recpire 1 to partiapate in the choiee. Th, only changes that couill be made unilateratly viere in the loci controlled by the manage, who crivid alter the incentives of other members single hrindedly under the cunditionas described earlier.

\subsection{Theary of the e wironment}

In all runs, all in lividuals were provided with the identival rough theory of the organizatior's cnvironment $A$ 64 $\times 64$ incidence matrix represented the fact that orders for a givin warehouse from a given factory werc somehow interdepiendent with other orders for that warehouse and with other ordurs from that factory. It conveyd nothing about the anture of the interdepondence Thus any individuals efforts to determine how to tospoad to an idea suggested by another bad only very weak theoretical gridan that identifind one subset contining about one half of the icci as being of greater fotential relevance.

\subsection{Initial policies and ideas}

All runs began with a policy of no orders. This infeasible policy has a disastrous value since violations of warehouse caparity constraints were a)ways subjected to a severe o,adratic penalty. All individuals began each run having no ideas abot t what to do other than the initial disastrous nocrter policy.

The large scale structure of the tasic organizational model is dispiayed in fg. 2. It shows fifteen member individuals in growps of three at each of the five arehouses and the sirteenth serving as menager. Each individual is shown adjacent to the set of four boc for which that member is responsible. Sixty loci control the patterns of shipping that in turn generate the urgatization's actual cost enewricuce. The other four are used by the 


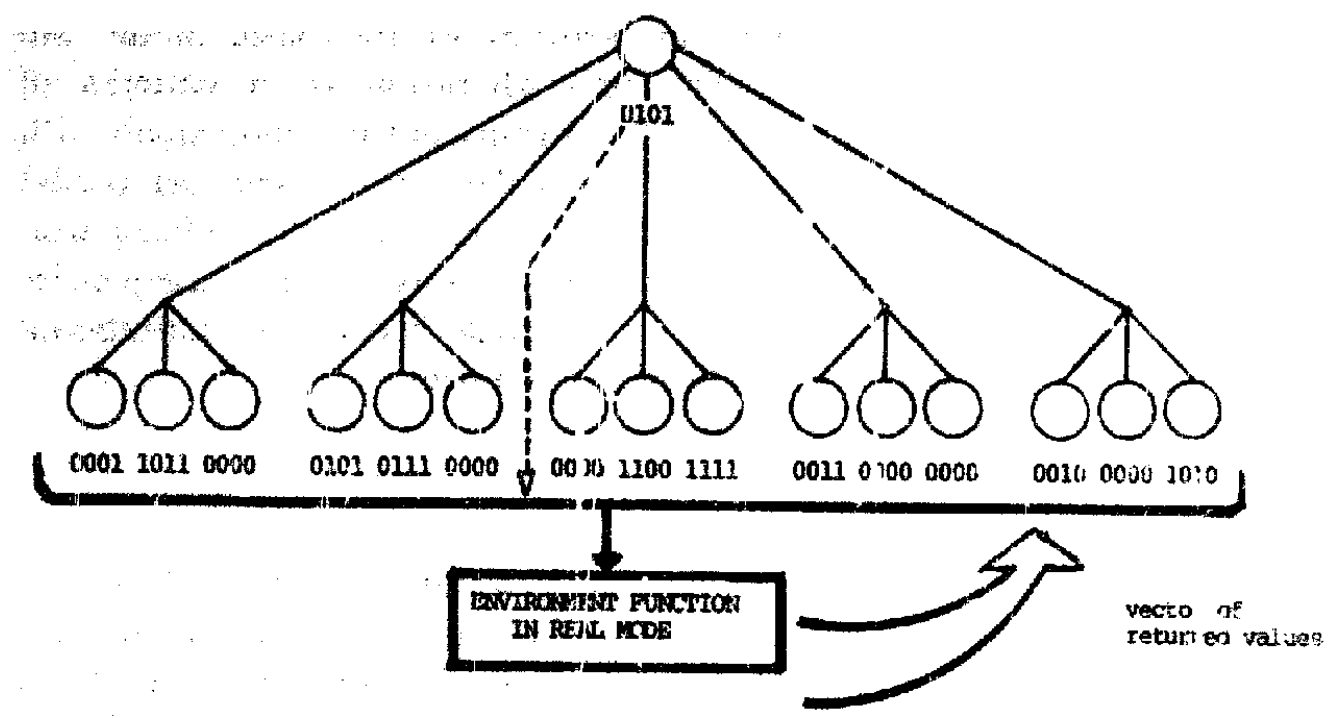

Fig. 2. Structure of the basic model. Eath individual responsible for four lot., binary encodings of integers. Three in lividuals per warehouse at five warehouses, each determining th is perits order for a warehouse from a factory. The loci of the sixteenth individial, the manager, ar rol incentives of the others. The policy reaching the environruent produces 1 vector of sixicen values. The undislying functions are in appendix $B$.

manager to adjust internal incentives. As each locus is a binary variable, there are $2^{6 / 2}$ possible patterns of shipment ordering. Organizationa adaptation occurs as a result of the structured interactic $n$ of the search ind choice processes of the mumber individuals. We wani to ascess th: contribution of that structurs to the cuality of thie $c$ ganization's adapive performance ir this very complex envircnment.

\section{The two variant models}

The resulis to be reported below are derived fro n the ferformance of thro models as each faced all ten variations on the "yutzig environmen. The three are the besic mojel, described above, anc two variants which ma labelled 'No-Talk' and 'Random-Meetings'.

In the No-Talk model, the talk processes described abrve are partia! disabled. Individuals still learn of ideas preffres by chers. bu th" in." go on to consider, or pass on to others, wh at they meculd aw prels

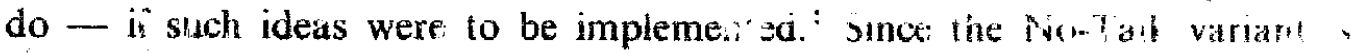
similar in all other respects to the basic model, it can be rur in the same the model environments in order to assess the spectio cuntribution the lis circuited interaction processes to overail crnanizational fos fomm.

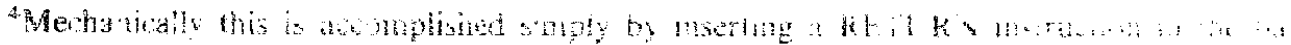

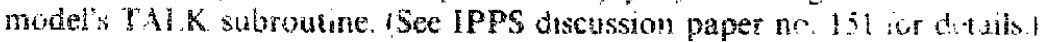


In the $\mathrm{R}$ andom-Kletings variant an features of the basic model are present, including talk juccesses. 76 only alte ation is in patterns of attendance at regular mee ings. Instoat of consisting of three individuals with

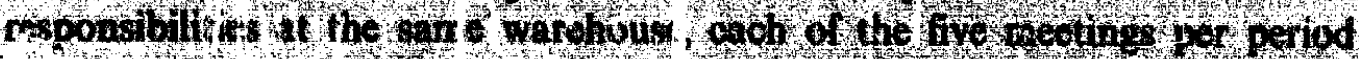

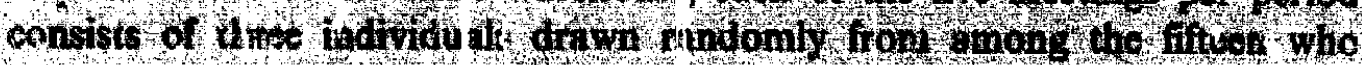
kave dinet policy tespons ibitied. Thit permits us 60 asess the consequences

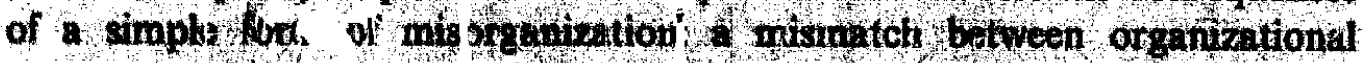
structure and the struchin of he prob ent environment?

\section{Resiliti}

moth

Hownon

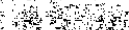

h. hon the

These extensive preliminaries nop thof us to teport the results of running each of the three inod organtation of in the ten erviromments that are variants on the Dantwg cansport pre blem Table 3 shows in its lefthand column the remarkable araptje power of the basic organizational model. In

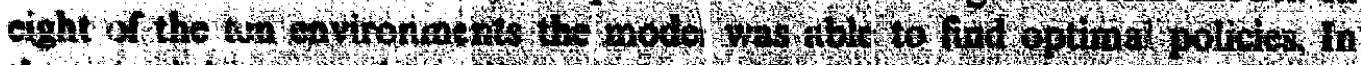

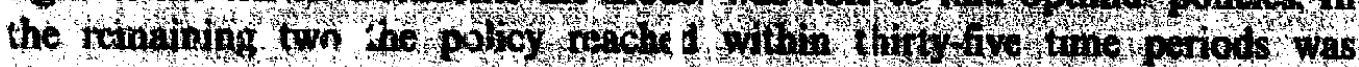
close to the optimum by two separtet measunes perent of range of feasible value, and number of coostratints viol tud by policy.

In ith central column of ti, tabls one sues the dramacic difierence in performance that follows from sort cir suiting the TALK subroutine of the basic organizational model The effert on the quahty of organirational adaptation is disastrous No optinn / sulations were obtainad Indeed, no feasible solutions were formd No policy at the ond of thirty five periods in the modified mrdel was within sight of the worl performance by the basic model.

In the right-hand colurn of the table it is evident that misorganization of the interaction processes damages organizational adaptation Not just any struciure to channel the prooesses embodied in th: TAKK subroutine twill do. Randonization of regular meeting attendanoe 10 ttems resilts in policies substantidy wors than those obtained by the tasic model in every one of the tex environments afthough TAL interaction was not disabled.

Alt ough toth variants wers far behind the performance of the basc mode th: $\mathbf{R}$ andom-Mretings nodel seems to have been less completely hotbind than the No-Talk variant, and the reasons are instructive. In two environtrents the Random-Meetings nodel lid attain feasiblt, though not optimen, policy, in two thers th lisastole region was closaly appreached. The No-Taik variant sever approacled easibility and failed to do so in a very striking way: nine of the ten runs have warehouse iso sstraints fully sutisfico while factory constraints tre virtually ignored. In No-Talk, Wrehouse meetings oscurred foutinely, and it was usually possible ior ar least one of the three individunls to think of a policy for the warehoure that satisined its constraist. Without the TALX subroutins however, the groups were unable 


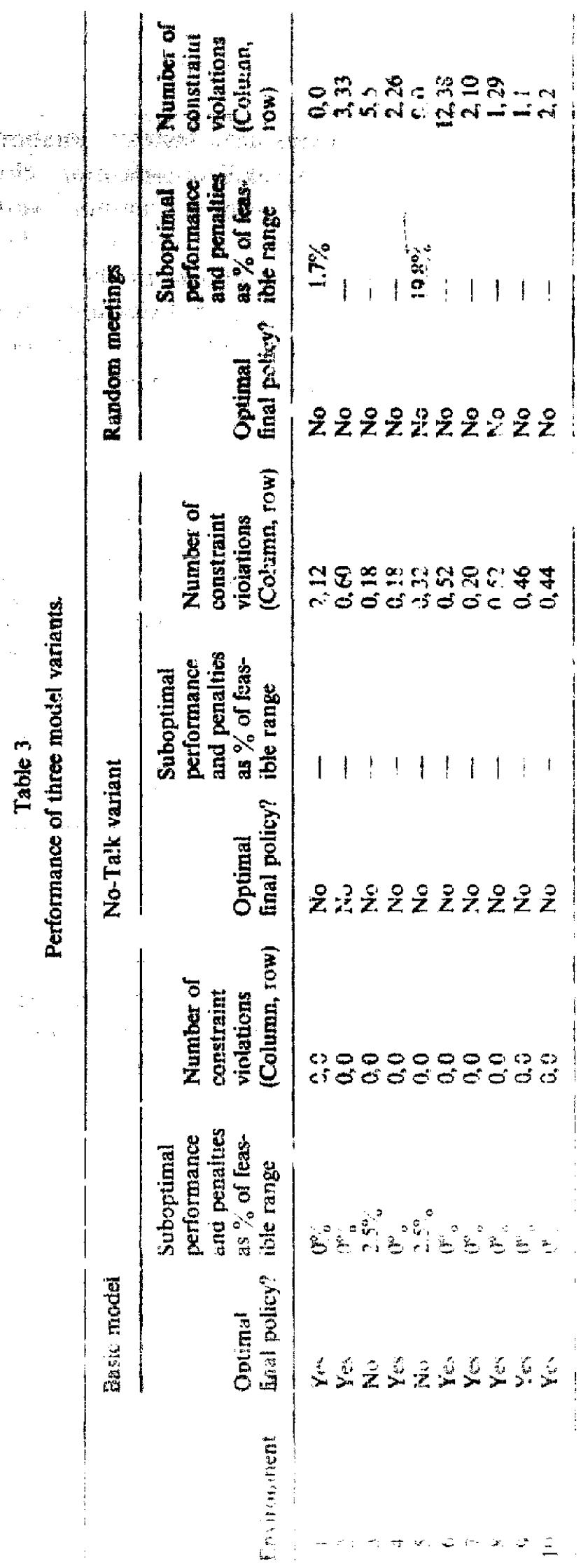


to find policies that did this without disastrous effects on factory constraints. In the resultint policy instablity, penaltes for fictory constraint violations

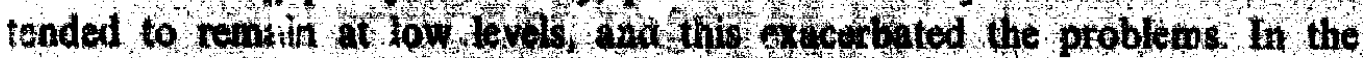
Random-Meotings nodel six of the asses have factory violation levels better than the best case $t$ No-Talk In this small organization, chance meetings of the individuals will include a pair from 8 coramon warehouse about forty percent of the time, and a pair tori a common factory will be presunt in about sevinty percent if the metob gs In these cases TALK has some chance to work - although with possible distortion introduced by the third party present. Even though its oppotiunities are unreliable and possibly distorted, the interaction process is powkfful enough to make substantial contributions in random noting This does not jecur in the No-Talk variunt.

These results establish three major conclusions: (1) an appropriate organization of boundedly rational indivilusils is capable of optimal or near optimal arlaytive performance in an environment of substantial complaxity, (2) high quality adaptive performence can be derived principally from the struatured interaction of the weak individuals who corapose the organization, and (3) an inappropriate structure for that interaction will achieve markedly inferior adaptation.

Strictly speaking these conclusions pertain, of course, only to the model world. Their signiicance beyond that depends on one's confidence in the rete.sace of the model world to the real one. That in turn must rest chiefly on the detailer sfforts made to incorporate widely observed characteristics of org inizations and their decision makers in the model. ${ }^{5}$

The conclusions about the modal world alone, however, are sufficient to establish that the decision making approach to organizations can account for tive occurnence of high quality organizational adaptation to very complex invironments. It can do so in a fashion which makes acuaptation a property of the organization rather than of its individual membirs, and which permits successful adaptation without guaranteeing it. This is a partial fulfillment of the pronise of Simon's (1954) profound treatment of organizational rontict und goals.

\section{In trperetation}

There are four points that should oe made in interpeting these model wisits. The first of these is that a cintral role a playsd by search processes when an orgatization confrorts a difficult enviromment. The point is hardily new, especially whet considering problem sol ing by incividuals [Simon

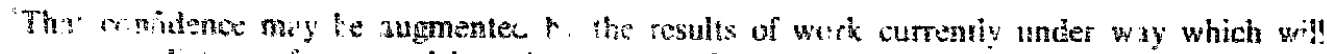

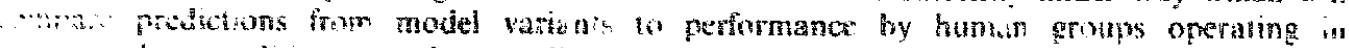

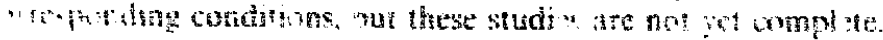


(1955 and 1956)]. Ii is worth stressing, however, that its formal suppori has been strengthened by recelt developraents in the theory of computational complexity and that the ass:rtion is, in the present case, made not about the sear h of individuais, but aly ut the search of organizations.

Since Simon's early articulation of bounded rationality arguments, there has emerged a very substantial literature on the restricted ability of individuals to consider alternatives [Slovic et al. (1977)] or to handle protrability concerts. That empirical literature has now been reinforced by theoretical analysis of what maken problems computationally complex Beginning with Cook's (:971, theorem theoretical compuier scientist:; have stablished that a daunting range of problems of eccnomic significanis are NF-cumplete. The conjecture has becone general that such protlems can require the consideration of an overwhelning number of alternatives and are therefore beyond the reach of any algorithm ruming in time bounded by a polynomial function of the number of variables in the problem [Ciarey and Johnson (1979)]. In this situation, search heuristics have become a topic of major research interest since exact optimal solutions tc problems of theoretical and economic significance are unlikely to be obtained [Karp (1976). Weiner (1975), Rosencrantz et al. (1974), Maffioli (1979)]. Computer science has thus come up against the same kinds of boundaries that limit the problem-solving activities of humar beings, and has had recourse to the same strategy in response. Combinatorial compilsxity makes the design of search processes a crucially importani activity.

Real organizations obviously face problenus at least as complex as the simplified models of those problem: formulated ir operations research an! computer science, so it is entirely plausible that the quality of search to at major determinant of the quality of organizational decision making. The corresponding result has been obtained from the model. The organizational search processes taking place in the TALK routine that communicates ideas and counterideas among individuals have been shown to be carable if generating optimal and near-optimal results in problem of extren: difficulty. ${ }^{6}$ It has also been shown that the jrgazizational $;$ arch rocesse, available when the interindividual activity is blocked, are in apabis: of hyl

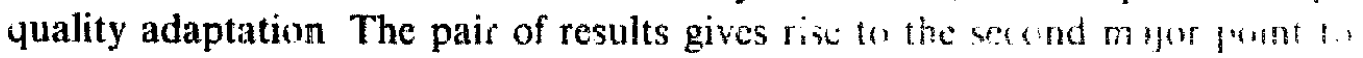

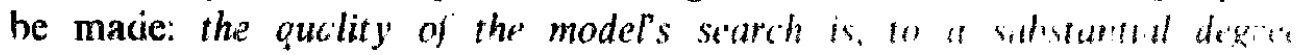
proper $y$ of the organization and not merily the summation if proptrias if individials who compose the organizotion in this moded and. so far it, i.". valid, in the world - interactions amoug individe ts censtivin a proscips source of phenomena that are distinctively orgatizitionst. Thruf interactum.

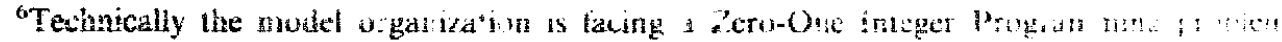

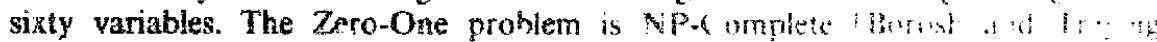

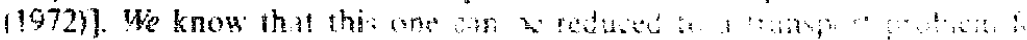

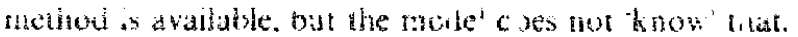


are $\mathrm{am}$ mol boune of he augmented tecision making powe which the org andertor can disolay,

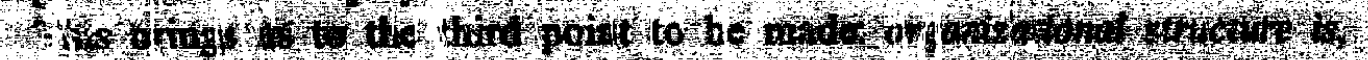

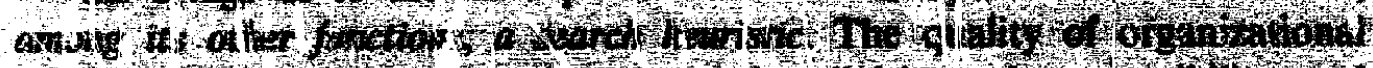

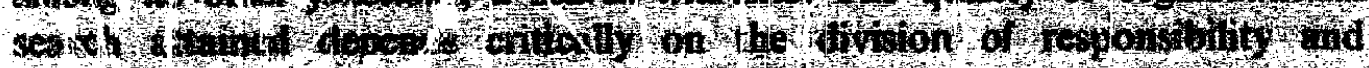

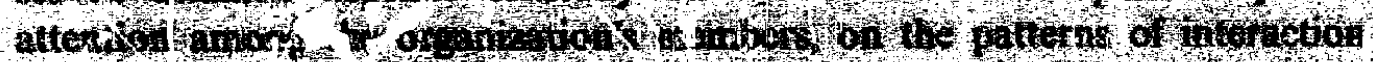

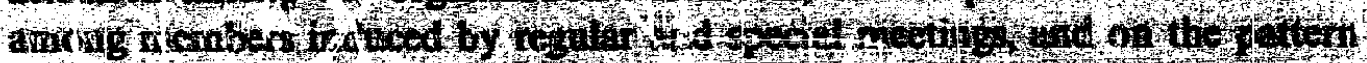

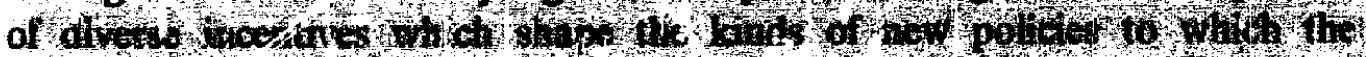

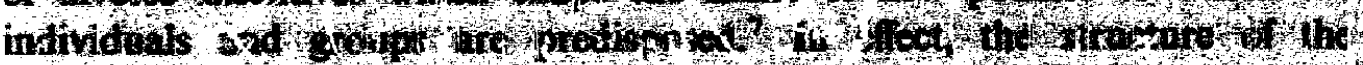

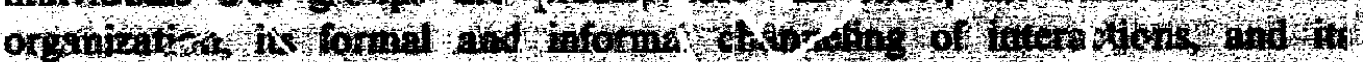

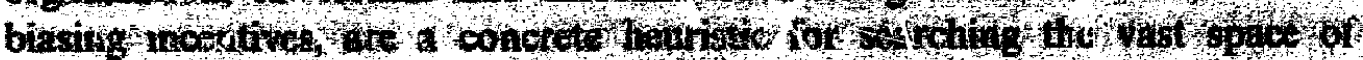

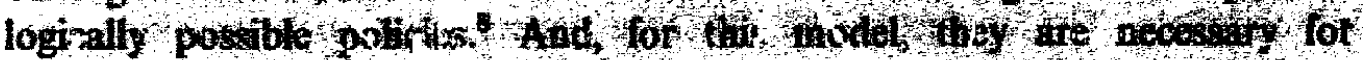
success:

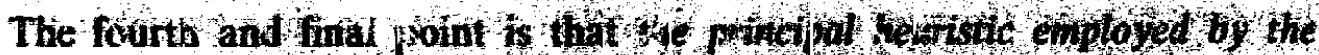

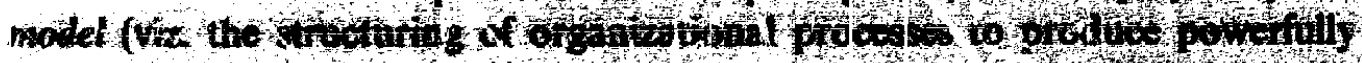

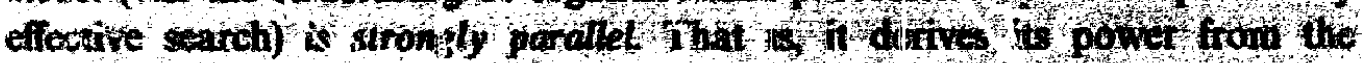

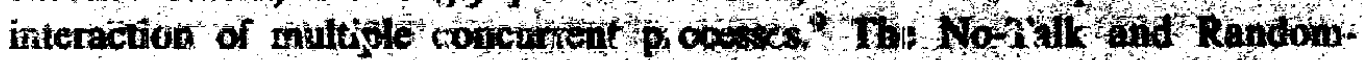

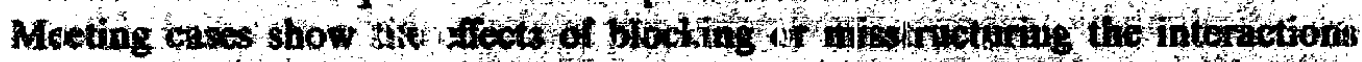
among to searches for betre policy being abtatutod by the onganzation's

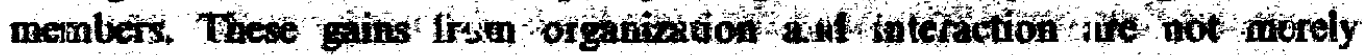
speed insorovements defivet from doing indexendent pirts of a job simultaneously. In the No-Talk varibit those advantages are stit being realized, but the results achieved are nonetwetes vatily iffertor to fiose of the basic model. The basic mode's atformage rests on the logical and temporal arpropriateness of the interactions to which it naturally gives rise.

The striking feature of the strongily parallet hevristic of the nodel is its ability to gat poweful seareh pelontonto ont of wat parts. This

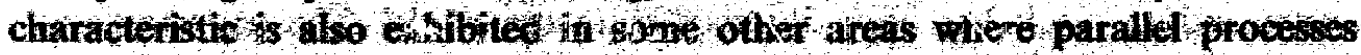
have boen shown to dramaticaly oupufons nonparalid alteratives for etrmple, Fahliman (1979) has showh that set mersoctions thaty be found in one or sey cyctes by his paralle in ormation netwotk no hatter what size the sets Typisal serizi procuses vill take a tine proportionat to set size. Thus Fatlmä's systen cat detemine almost immediately, es can most

"A cotrapaion paper, "Confict and Complexiny" explores this aspect in more detail [Coben (1982). It shows that there are cilcumstances of which the divergence nincentives may protect

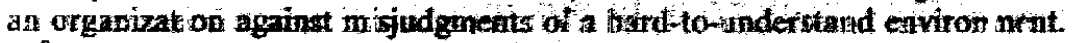

${ }^{8}$ Orber functions are cleary served by gructure See, $5 \mathrm{~g}$, (crenter (1980), or Thompson (1967).

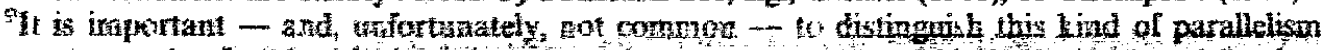

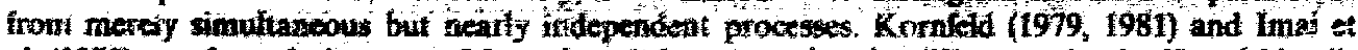

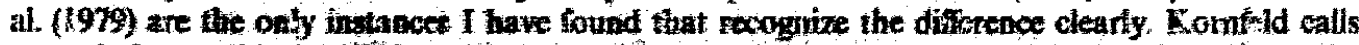

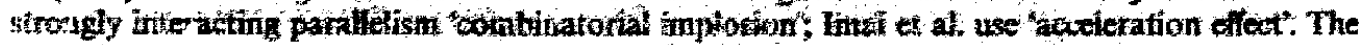
acecution on the conguter progran antodying the rodel if of course, serial by virtue of the

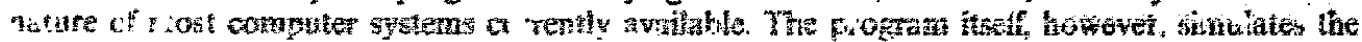

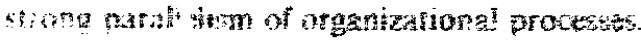


humans, that it knows of no insects larger than a horse. ${ }^{10} \mathrm{~A}$ šrial system not desigued in advance for just this type of question wili bog down in the large size of the sets. A second extmple is provided by the work of John Holland (1975) on heuristis explotation of high-dimensionality non-linear functions. $\mathrm{He}$ and his colleagues have shown that it population of about a hundre individuals' interacting according to rules borrowed from genetics can find global optima in such conditions much more reliably than standard hill elimbing techniques using comparatile amounts of computer time." A third exarple is provided by the remarkable improvements in computation pronu by highly parallel algor thms exploiting the massive simultaneity that wil be possible with Very Large Scale Integrated architectures. Mead and Curvay (1980, pp. 264-265) suggest that 'analogies with human structur s tnay help to suggest the kinds of behavior we might achieve in computaticnal structures... [Parallelism] is widely exhibited in humar organizatizus ... The design of computers and of algorithms has yet to $s, \mathrm{~h}, \mathrm{v}$ the ingenusty reflected in human organizations'.

If the essential problem of organizational adaptation is coping successf $m y$ with the complexity of the environment, and if we believe the individuais in the organization are generally not capable of solving its whele problen: alone, this property of generating powerful performance from interactions of weak components will have to be present for high quality idaptation to occur. The results reported above show that interacting parallel processes broadly consistent with modern empirical studies of r,ganizations and their decision makers are sufficient to produce impre sve adaptation. These processes allow the basic model to meet a stringent and essential performance test that previous accounts of organizntional adiptation tiave not faced and probably could not meet. As a result, fundamental questions about the limits and sources of organizational rationality may now be subjected to a more rigorous and revealing thoretical examination.

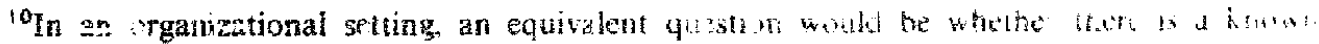
poicy that salisties several given wontrains.

In fact, thus dtmonsiration by Holland provided:

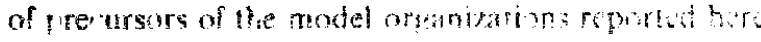




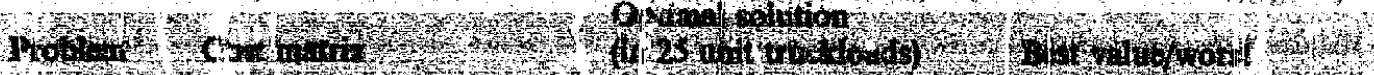

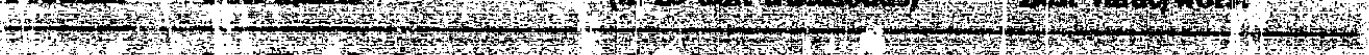
H.t.

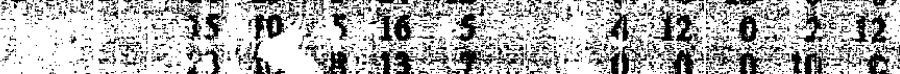

6091

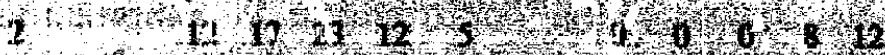

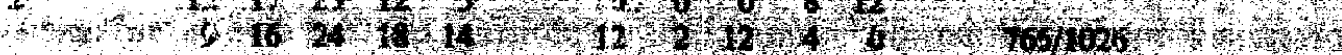

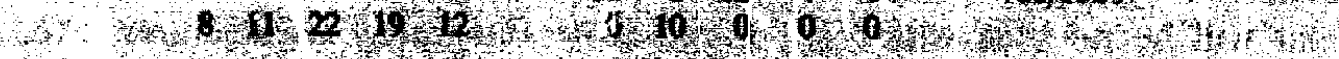

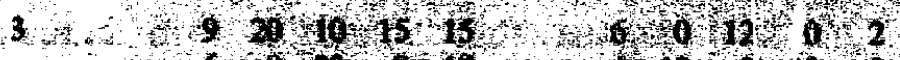

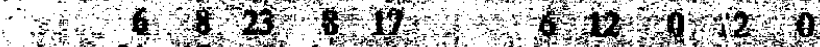

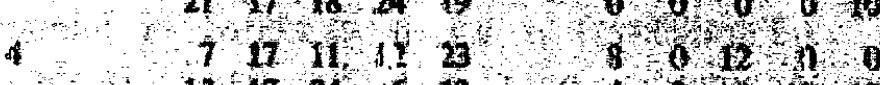

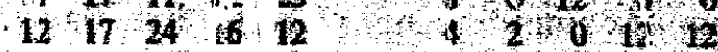
$14 \quad 5 \quad 22 \cdot 5 \cdot 24$
$010,0 \quad 0$,
6061124

oratos

Hown

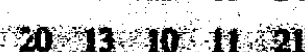

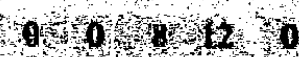

10, 16 22, 60

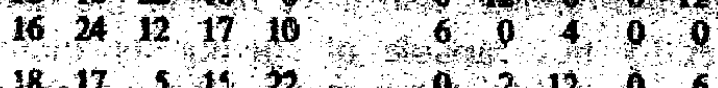

6

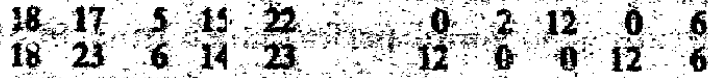

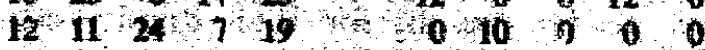

$858 / 1200$

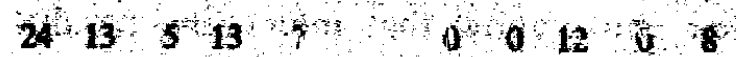

\& 12.16 1 $21,12,6,0$ 12 0

4761142

$12613240,0,50044$

7

15201621000012

$6-21242313 \quad 0260120$

106811600600

$742 / 1078$

9

18 $9^{15} 5$ if $\quad 0$ o 8120

$12615.917 \quad 1212 \quad 4 \quad 0 \quad 2$

$15.5420,0,00000$

$570 / 914$

10

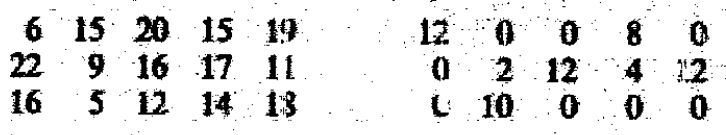

$652 / 1082$

\section{Appendix B}

\section{Definitions}

$x_{i j} \equiv$ vrder level, $0 \leqq x_{i j} \leq 15$

$x_{i j}$ may be interpreted as 'truckloads'. $1 \leqq i \leqq 3$, factorizs, $1 \leqq j \leqq 5$, warehousec,

$y_{a^{\prime},} \equiv$ value for policy ret Irned to individuel $(a, b)$, 
$\epsilon_{f}=$ cast of shijping one ordered Iruckload from $i$ to $;$,

$r_{i} \approx$ toti $i$ of orders from factory $i=\sum_{j=1}^{5} x_{i j}$,

$p=\left|r_{1}-20\right|+\left|r_{2}-30\right|+\left|r_{3}-10\right|=$ sum of factory capacity violations,

$w_{j}-\sum_{i=1}^{3} x_{i}-12=$ capacity violation at warehouse $j$.

For directly responsible individual $(a, j)$ ordering from factory a for warehouse b,

$$
y_{\mathrm{ab}}=\sum_{i=1}^{3} \sum_{j=1}^{5} x_{i_{j}} \ell_{i j}+(0.55 p)(c(K+1)-c(K))+\sum_{j=1}^{5}\left(5 w_{j}\right)^{2}
$$

The ind vidual acts to minimize this function of total shipping cost at all warthouses, factory capacity violations, and all warehouse capacity viclations, $q(K)$ is the $K \mathrm{th}$ smullest unit cost and $K$ is increased by the manager each time organizational policy has been unchanged $\mathrm{fcr}$ three consecutive pericds.

For the manager

$$
y_{\mathrm{m}}=0.0001 \sum_{i=1}^{3} \sum_{j=1}^{3} x_{i j} c_{i j}+p
$$

The scaling factor (6.0001) estat lishes a lexiccgraphic preference fur r vucin? $p$, factory constiaint violations, and thereafter for alterr atives that winimir: totai shipping cost.

\section{Neferences}

Aldrich, H., 1979, Oryanizations and environments (Pnentic. Hall. Englewood Clif , N.)

A arterson, J, 1980, Cognitive psychology and its implicatio is (Freman, San Franc sco, $C$ il

Eyrosh, I. and L.B. Treybig 1976, Bounds on positive integral solutions of linear dupi at thite squations, Procedings of Americin Mathematical sur iety 55, 299-30.4.

Cohen, M., 198.0, Documentation of an organizationnt trodelling system. Discussion paper ni.

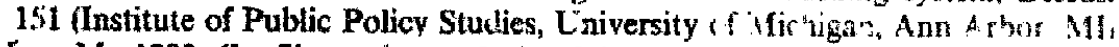

Cohen, M., 1982, Conflict and complexity, Discussior faper so 153, (1/stivile of Puble pibs: Siudies, An: Arbor, MI) revised.

C. sol, S.A., 1971, The complexity of theorem provirg rocedures, frec id Annut as Symposium on Theory of Cunputing (Association for Cont ing Machnery. Aeu $Y_{0}$, )

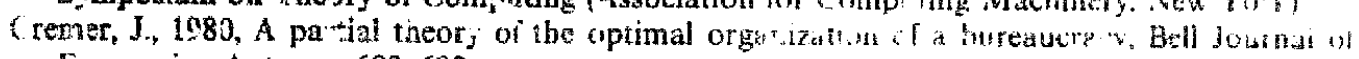
Exononics, Autumn, 683-693.

Hstes, W.K., 1978, Handbook of learning and cognitive proci ises, Vol. 6 (Erlbaun, in)

Frhlman, si. 1979, NETL: A system for representing and using resl-world knowledere inf Press, (amoridge, MA). 


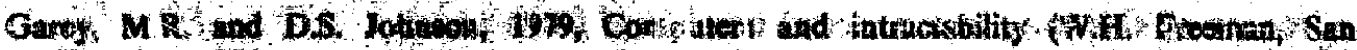
How $\mathrm{CA}$

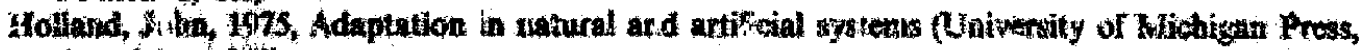
Ain At" or, NII

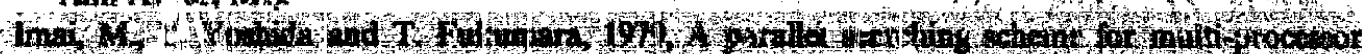

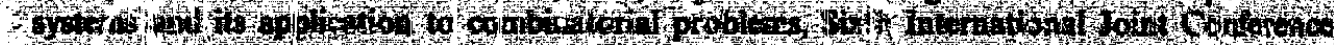

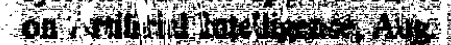

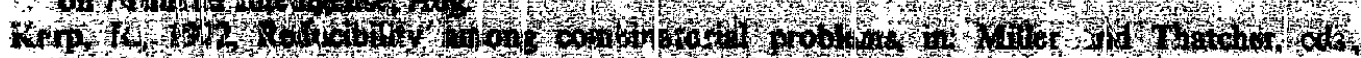

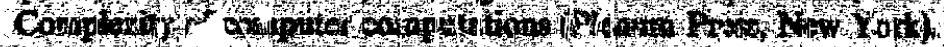

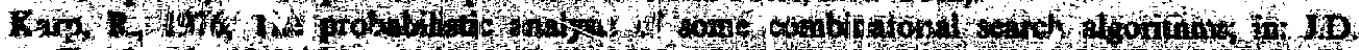

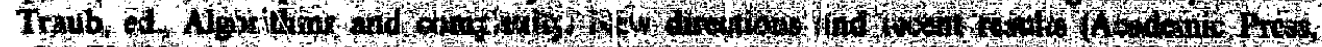
(a) $\operatorname{Tor} 1$

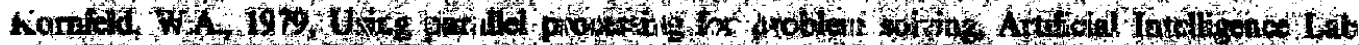
hamo

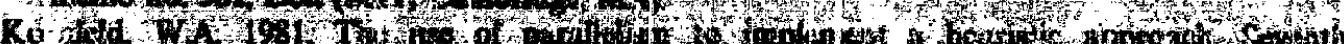

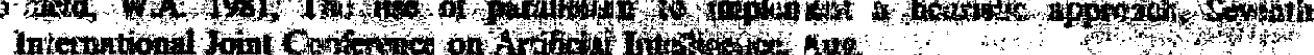

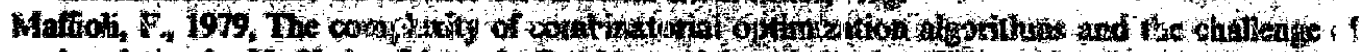

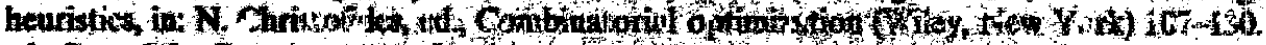

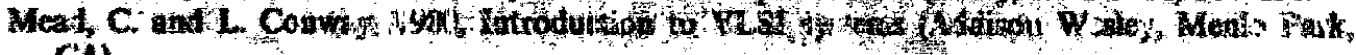
CA.

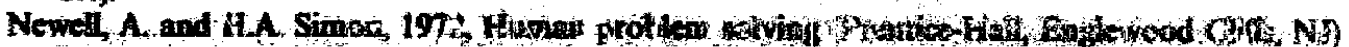

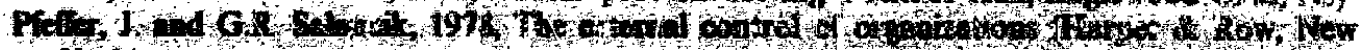
York)

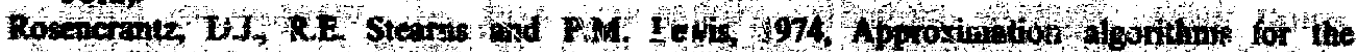

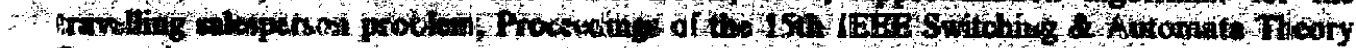

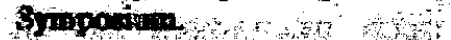

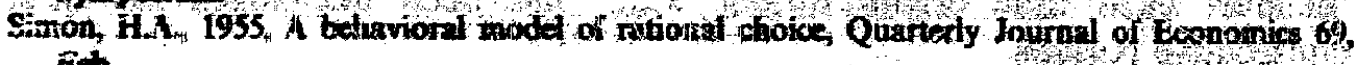
Fob.

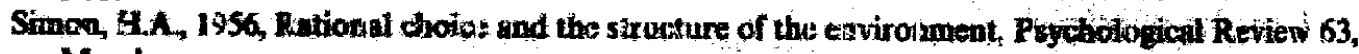
March

Simcn, HA, 1962 , The inchiteciure of complaxity, frowetings of the Arserican Philosophical Society 106, Jhoc, $457-482$

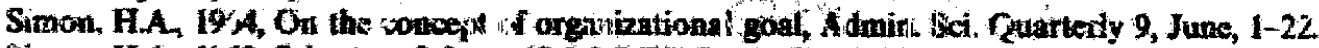

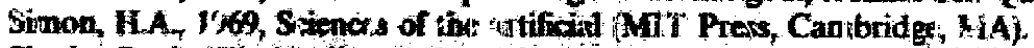

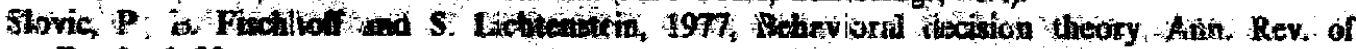

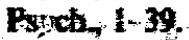

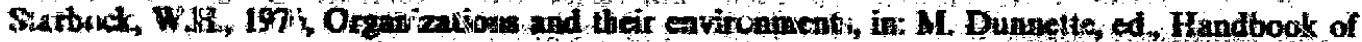

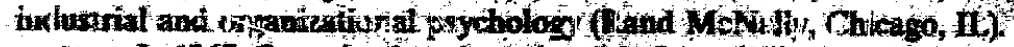

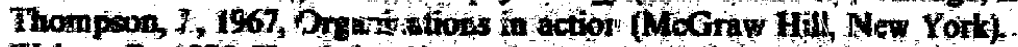

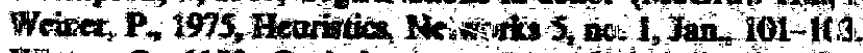

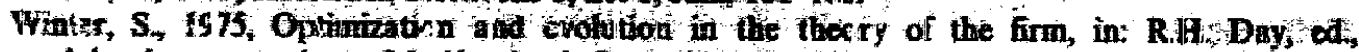
Adap iw: cononis roodels (Academic Preis, New Yort) 